\title{
Biodegradable mulch instead of polyethylene for weed control of processing tomato production
}

\author{
Alicia Cirujeda • Joaquin Aibar • Álvaro Anzalone • \\ Lluís Martín-Closas • Ramón Meco • \\ Marta María Moreno - Alfoso Pardo • \\ Ana María Pelacho • Ferran Rojo • Aritz Royo-Esnal • \\ María Luisa Suso • Carlos Zaragoza
}

Accepted: 8 February 2012 /Published online: 14 March 2012

(C) INRA and Springer-Verlag, France 2012

\begin{abstract}
Black polyethylene (PE) film is used for mulching in processing tomato (Lycopersicon esculentum P. Mill.) in Spain achieving a generally high weed control but causing a serious waste problem. Few herbicides are available for tomato, so that a biodegradable mulching is the desired solution which should provide high yield, high weed control and be economically available. For 3 years, the same field trial was carried out in four areas of Spain using the following mulch materials in processing tomatoes: (1) untreated control, (2) manual weeding, (3) PE, black, $15 \mu \mathrm{m}$ thick, (4) and (5) two types of biodegradable plastic mulch, black, $15 \mu \mathrm{m}$, (6) oxo-degradable plastic mulch, black, $15 \mu \mathrm{m}$, (7) paper mulch, black, $85 \mathrm{gm}^{-2}$, (8) kraft paper mulch, brown, $140 \mathrm{gm}^{-2}$ and (9) barley straw, $1 \mathrm{~kg} \mathrm{~m}^{-2}$. Weed control, yield and economic aspects were analysed. Most frequent
\end{abstract}

A. Cirujeda $(\bowtie) \cdot$ C. Zaragoza

Unidad de Sanidad Vegetal,

Centro de Investigación y Tecnología Agroalimentaria (CITA),

Avda. Montañana 930,

50059 Zaragoza, Spain

e-mail: acirujeda@aragon.es

J. Aibar

Universidad de Zaragoza. Escuela Politécnica Superior,

Ctra. de Cuarte $\mathrm{s} / \mathrm{n}$,

22071 Huesca, Spain

Á. Anzalone

Departamento de Fitotecnia, Decanato de Agronomía,

Universidad Centroccidental "Lisandro Alvarado",

Barquisimeto, Venezuela

L. Martín-Closas · A. M. Pelacho · F. Rojo • A. Royo-Esnal Departamento de Hortofruticultura, Botánica y Jardinería, ETSEA-Universitat de Lleida,

Alc. Rovira Roure 191,

25198 Lleida, Spain weed species were Convolvulus arvensis, Chenopodium album and Amaranthus spp. Here, we showed that despite differences in weed species, soil type and years, weed competition caused a similar yield decrease in all locations. A common regression coefficient could be estimated indicating that weed competition was responsible for a yield decrease of 3.3 to $4.4 \mathrm{t} \mathrm{ha}^{-1}$ for each $10 \%$ of efficacy loss. Weed control was high for biodegradable plastics, paper mulches and PE ranging between $80 \%$ and $100 \%$ for all of them; also, yield was similar for all plastic and paper mulching treatments ranging between $72 \%$ and $108 \%$ of the yield achieved by PE. Here, we demonstrate that technically viable biodegradable alternatives exist for all four locations. From the economic point of view, PE gave highest benefits, mainly due to its low market price and to high yields despite

\section{R. Meco}

Servicio de Investigación y Tecnología Agraria, Junta de Castilla_-La Mancha,

Toledo, Spain

M. M. Moreno

Escuela Universitaria de Ingeniería Técnica Agrícola, Ronda de Calatrava 7,

13071 Ciudad Real, Spain

A. Pardo $\cdot$ M. L. Suso

SIDTA-CIDA,

Ctra. Mendavia-Logroño $\mathrm{km} 88$,

26071 Logroño, Spain 
removal costs, showing that its substitution will depend on prohibition. For locations with low-density weed infestations, manual weeding can be an alternative.

Keywords Polyethylene · Biodegradable mulch · Paper. Barley straw

\section{Introduction}

Weeds are responsible of the highest potential loss in the most important crops worldwide (34\%; Oerke 2006) and diminish processing tomato production (Lycopersicon esculentum P. Mill.) due to competition with water, nutrients and light (Weaver and Tan 1983; Patrap et al. 1997). Most damaging species are Solanum nigrum with infestation thresholds of only one plant per lineal meter in transplanted tomato (Maillet and Abdel Fatah 1983). High infestations of Cyperus rotundus (166 plants per lineal meter), a common perennial sedge in Mediterranean irrigated lands, can cause losses of 53\% (William and Warren 1975). Main available tools for weed control are preventive cultural methods, mechanical weed control and herbicides; but the combination of these methods is usually the most effective strategy (Anderson 2007). In Spain, few herbicides are available for processing tomato and farmers' alternate herbicide use with black polyethylene mulch (PE). Besides environmental problems (Tabaglio et al. 2008), the main drawback of herbicide use is the need of combining it with other techniques because some weed species like $S$. nigrum, C. rotundus and Orobanche ramosa are poorly controlled (Tei 2001) while the main disadvantage of mulching is the waste generation. Mechanized harvest breaks the PE mulch which makes difficult to remove the plastic pieces completely. The European Directive 2006/12/EC encourages reduction in the production of waste by promoting clean technologies and products that can be recycled and reused and which has been adopted by the First Spanish National Plan on Residues of Plastics Used in Agriculture in 2006 (MARM 2011a, b). The presence of plastic debris in the fields also has a negative influence on subsequent crops such as spinach (Spinacia oleracea L.) or peas (Pisum sativum L.) for canning because plastic residues could contaminate packaging during the harvest process.

The easiest alternative for farmers to PE mulching are biodegradable plastics because the same mechanized process designed for PE can be used. However, high prices and lack of Cyperus spp. control with these materials (Anzalone et al. 2010) led us to investigate the effect of other mulch types on weed control and crop yield in processing tomatoes. Other available alternatives are oxo-degradable plastic, paper mulch and barley straw. The main advantage of oxodegradable plastic is the low cost and the easy installation but the main inconvenience is that the buried part does not suffer degradation and needs to be exposed to light and air to degrade because the degradation of oxo-degradable plastics is a result of oxidative and cell-mediated phenomena, either simultaneously or successively (Scott 2005). The use of paper mulch started already in the 1970s (Vandenberg and Tiessen 1972) but was replaced by PE because of its better mechanical properties in elasticity and avoiding water evaporation. The disadvantages of PE caused a new interest in paper mulch and at present, the most recent research in Italy focus on paper coated with other materials as blends based on polyhydroxyalkanoates (Salemi et al. 2008). The main disadvantages of using paper mulch are the heavier coils, slower mulching speed and the need of a careful installation to avoid fractures (Harrington and Bedford 2004). However, an interesting property of paper mulch is the ability to control C. rotundus (Shogren and Hochmuth 2004; Anzalone et al. 2010).

Barley is the main winter cereal in Spain, accounting for a planted area of 3,500,000 ha (MARM 2011a, b), so barley straw is the most commonly used product for organic mulch. In most of the found research work, the general trend is that straw mulch has positive effects on crops due to increased soil moisture and increased weed control but achieves a notso-high yield improvement compared to black plastic mulch (Woldetsadik et al. 2003; Alcántara et al. 2007; Anzalone et al. 2010). In most cases, weed control with straw is also lower than with PE, which probably causes, in many cases, the lower yield.

Processing tomatoes occupied 34.951 ha in 2008 in Spain (MARM 2011a, b). Climatic characteristics as well as soil types vary within the different production areas and biodegradable mulches may have different agronomic behaviour depending on the area. Therefore, field trials were established in four different locations where processing tomato is grown.

The objective of this work was to evaluate the effect of several biodegradable mulches on weed control and yield of processing tomato in different areas of Spain (Fig. 1) to find an alternative to standard black PE mulch in order to reduce the waste problem.

\section{Materials and methods}

\subsection{Field trials}

The same field trial was established at four locations in Spain during 2006, 2007 and 2008 (Table 1). The experimental design was a randomized block design with at least three replicates of nine treatments: (1) untreated control, (2) manual weeding (three times along the crop cycle), (3) conventional plastic mulch (black PE, $15 \mu \mathrm{m}$ thick), (4) biodegradable plastic mulch (black Mater-Bi@) $15 \mu \mathrm{m}$ thick), (5) 


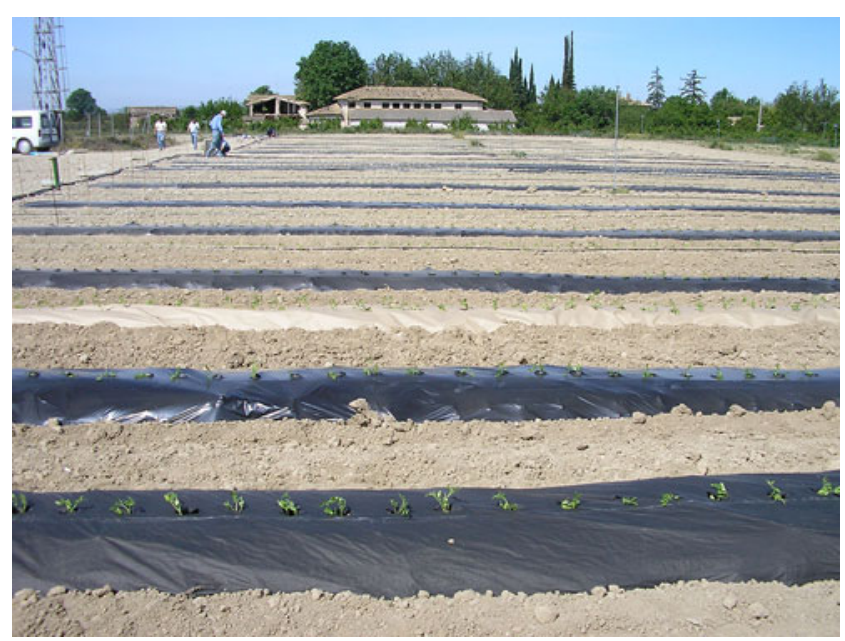

Fig. 1 View of one of the field trials where different biodegradable mulching materials were tested at Almudévar, Aragón, in 2007

biodegradable plastic mulch (black Biofilm@), $17 \mu \mathrm{m}$ thick), (6) oxo-degradable plastic mulch (black Enviroplast $\mathrm{C}, 15 \mu \mathrm{m}$ thick), (7) paper mulch (black MimGreen $\odot$, $85 \mathrm{gm}^{-2}$ ), (8) paper mulch (brown SaikraftC, $140 \mathrm{gm}^{-2}$ ), (9) barley straw $\left(1 \mathrm{~kg} \mathrm{~m}^{-2}\right)$. Barley straw was provided locally and the dose was determined in previous experiments (Anzalone et al. 2010). Straw was applied 10 days after transplanting.

Soil preparation included soil tillage and formation of 0.8 -m-wide raised beds with a distance of $1.5 \mathrm{~m}$ between the centre of the beds. Seeds of the processing tomato variety 'Perfect Peel' were used and plants transplanted at $0.2 \mathrm{~m}$ plant spacing. Each experimental plot consisted in a crop row of $20 \mathrm{~m}$ long. Weed assessments were recorded in four fixed areas per plot, tomato yield was determined outside these areas to avoid any influence. Planting date, mulching date and type of fertilization were different depending on the location (Table 1) and the crop was conducted fully organically at Lleida. The crop was drip irrigated with a $16 \mathrm{~mm}$ diameter pipe per bed with $20 \mathrm{~cm}$ spacing between emitters. The irrigation system was configured so that different treatments could be irrigated separately. The moisture values obtained by dielectric sensors (Aquameter ECH2O, Decagon or Diviner, Sentek) were used to determine the appropriate amount of irrigation required to avoid moisture stress and to maintain the same soil moisture level at each treatment.

Weeds were counted at 21, 42 and 63 days after transplanting (DAT) in each plot in $20 \times 100 \mathrm{~cm}$ frames next to the tomato plants avoiding the planting holes. Weed soil cover was also assessed at the same moments. In the manually weeded plots, weeds were removed, when necessary, three times during the cropping cycle. Weed biomass of the plants growing in the counting frame was collected at 63 DAT and dried until constant weight at $60^{\circ} \mathrm{C}$.

Tomato was harvested when ripe fruits accounted for more than $80 \%$ of total fruits in each treatment. A minimum of five plants per plot were harvested, fruits classified in red commercial fruits, green fruits with a diameter greater than

Table 1 Location of the fields, year of experiment, soil and fertilization characteristics, mulching, planting and harvest dates at the different locations

\begin{tabular}{|c|c|c|c|c|c|c|c|c|}
\hline Location & Latitude & Longitude & Year & Soil type & $\begin{array}{l}\text { Mulching } \\
\text { date }\end{array}$ & $\begin{array}{l}\text { Planting } \\
\text { date }\end{array}$ & Harvest date & Harvest (DAT) \\
\hline $\begin{array}{l}\text { Aragón } \\
\text { (Almudévar) }\end{array}$ & $42^{\circ} 1^{\prime} 50.48^{\prime \prime} \mathrm{N}$ & $0^{\circ} 35^{\prime} 5.73^{\prime \prime} \mathrm{W}$ & 2006 & Silty clay & $22 / 05 / 06$ & $25 / 05 / 06$ & $17 / 09 / 06$ & 116 \\
\hline Almudévar & $42^{\circ} 1^{\prime} 50.48^{\prime \prime} \mathrm{N}$ & $0^{\circ} 35^{\prime} 5.73^{\prime \prime} \mathrm{W}$ & 2007 & Silty clay & $01 / 06 / 07$ & $04 / 06 / 07$ & $18 / 09 / 07$ 01/10/07 & 106,122 \\
\hline Montañana & $41^{\circ} 43^{\prime} 50.16^{\prime \prime} \mathrm{N}$ & $0^{\circ} 48^{\prime} 24.15^{\prime \prime} \mathrm{W}$ & 2008 & Clay loam & $22 / 05 / 08^{\mathrm{a}}$ & $18 / 06 / 08$ & $06 / 10 / 08$ & 109 \\
\hline $\begin{array}{l}\text { Logroño } \\
\text { (Agoncillo) }\end{array}$ & $42^{\circ} 28^{\prime} 8.654^{\prime \prime} \mathrm{N}$ & $2^{\circ} 17^{\prime} 39.276^{\prime \prime} \mathrm{W}$ & 2006 & Silty clay & $02 / 05 / 06$ & $10 / 05 / 06$ & $22 / 08 / 06-04 / 09 / 06$ & $104-117$ \\
\hline Agoncillo & $42^{\circ} 28^{\prime} 8.654^{\prime \prime} \mathrm{N}$ & $2^{\circ} 17^{\prime} 39.276^{\prime \prime} \mathrm{W}$ & 2007 & Silty clay & $08 / 05 / 07$ & $11 / 05 / 07$ & $30 / 08 / 07-03 / 09 / 07$ & $111-115$ \\
\hline Agoncillo & $42^{\circ} 27^{\prime} 56.594^{\prime \prime} \mathrm{N}$ & $2^{\circ} 17^{\prime} 39.411^{\prime \prime} \mathrm{W}$ & 2008 & Loam & $07 / 05 / 08$ & $13 / 05 / 08$ & 01/09/08-03/09/08 & $111-113$ \\
\hline $\begin{array}{l}\text { Lleida (Vilanova } \\
\text { de Bellpuig) }\end{array}$ & $41^{\circ} 36^{\prime} 38^{\prime \prime} \mathrm{N}$ & $0^{\circ} 57^{\prime} 36^{\prime \prime} \mathrm{E}$ & 2006 & Silty clay & $06 / 05 / 06$ & 08/05/06 & $25 / 08 / 06$ & 109 \\
\hline $\begin{array}{l}\text { Vilanova de } \\
\text { Bellpuig }\end{array}$ & $41^{\circ} 36^{\prime} 38^{\prime \prime} \mathrm{N}$ & $0^{\circ} 57^{\prime} 36^{\prime \prime} \mathrm{E}$ & 2007 & $\begin{array}{l}\text { Silty clay } \\
\text { loam }\end{array}$ & $28 / 05 / 07$ & $30 / 05 / 07$ & $10 / 09 / 07$ & 105 \\
\hline $\begin{array}{l}\text { Vilanova de } \\
\text { Bellpuig }\end{array}$ & $41^{\circ} 36^{\prime} 38^{\prime \prime} \mathrm{N}$ & $0^{\circ} 57^{\prime} 36^{\prime \prime} \mathrm{E}$ & 2008 & Silty clay & $12 / 06 / 08$ & $13 / 06 / 08$ & $02 / 10 / 08$ & 111 \\
\hline $\begin{array}{l}\text { Ciudad Real } \\
\text { (Ciudad Real) }\end{array}$ & $39^{\circ} 0^{\prime} \mathrm{N}$ & $3^{\circ} 56^{\prime} \mathrm{W}$ & 2006 & $\begin{array}{l}\text { Sandy clay } \\
\text { loam }\end{array}$ & $17 / 05 / 06$ & $18 / 05 / 06$ & 06/09/06-14/09/06 & $111-119$ \\
\hline Ciudad Real & $39^{\circ} 0^{\prime} \mathrm{N}$ & $3^{\circ} 56^{\prime} \mathrm{W}$ & 2007 & Loam & $16 / 05 / 07$ & $18 / 05 / 07$ & 27/08/07-03/09/07 & $101-108$ \\
\hline Ciudad Real & $39^{\circ} 0^{\prime} \mathrm{N}$ & $3^{\circ} 56^{\prime} \mathrm{W}$ & 2008 & Loam & $27 / 05 / 08$ & $04 / 06 / 08$ & $15 / 09 / 08-17 / 09 / 08$ & $103-105$ \\
\hline
\end{tabular}

$D A T$ days after transplanting

${ }^{\text {a }}$ 18/06/08 Saikraft ${ }^{\circledR}$ and Mater-Bi ${ }^{\circledR}$ 
$25 \mathrm{~mm}$ and non-commercial fruits (green fruits with diameter lower than $25 \mathrm{~mm}$ and rotten or damaged fruits) and weighed separately. The sum of red and big green fruits was considered for yield calculations.

\subsection{Data analysis}

Mean efficacy of weed control was calculated as \% efficacy $=100-\left[\left(T_{\mathrm{t}} / T_{\mathrm{u}}\right) \times 100\right]$ where $T_{\mathrm{t}}$ is the weed cover in each treatment and $T_{\mathrm{u}}$ is the weed cover in the untreated control plots.

Efficacy was $a \sin (\sqrt{(x / 100)})$ transformed, weed biomass needed $\sqrt{x}$ transformation and yield needed in some cases $(x)^{2}$ transformation to satisfy normality and variance homogeneity following the indications of the Box-Cox transformation (Bowley 1999). Block was nested with year, which was taken into account in the ANOVA model using the statistic package SAS (SAS Institute, 1991).

\subsection{Weed competition}

The weed-free plots established by manual weeding allowed to assess the relevance of weed competition in reducing tomato yield. Yield loss was calculated following: $\%$ yield loss $=100-$ $\left(Y_{\mathrm{u}} / Y_{\mathrm{m}} \times 100\right)$, where $Y_{\mathrm{m}}$ is tomato yield in the manually weeded plots and $Y_{\mathrm{u}}$ is the yield in the untreated control plots.

Regression was used to describe the relationship between tomato yield and weed control. A linear regression analysis of yield on weed control efficacy was performed in each experiment with Systat $(12$ linear regression module. To test the homogeneity of the obtained regression coefficients, the method described by Dagnelie (1975) was applied to determine whether or not they can be considered to be estimates of a common coefficient.

\subsection{Economic study}

\subsubsection{Costs and incomes}

General costs including plantation, fertilization, irrigation etc., accounted for 6,278 € ha ${ }^{-1}$ for all treatments (Gutiérrez et al. 2005; updated with Consumer Price Index through www.ine.es/calcula). Costs of mulching material were obtained in the Spanish market from Zaragoza suppliers in 2010 considering covering $60 \%$ of the surface: $181 € \mathrm{ha}^{-1}$ for PE, $966 € \mathrm{ha}^{-1}$ for Mater-Bi ${ }^{\circledR}, 818 € \mathrm{ha}^{-1}$ for Biofilm ${ }^{\circledR}$, $296 € \mathrm{ha}^{-1}$ for Enviroplast ${ }^{\circledR}, 843 € \mathrm{ha}^{-1}$ for MimGreen ${ }^{\circledR}$, $429 € \mathrm{ha}^{-1}$ for Saikraft ${ }^{\circledR}$ and $200 € \mathrm{ha}^{-1}$ for barley straw (considering $36 € \mathrm{t}^{-1}$, application dose $1 \mathrm{~kg} \mathrm{~m}^{-2}$ ). Mulch installation costs with machinery were $65 € \mathrm{ha}^{-1}$ for the plastics, which was increased additionally by $20 € \mathrm{ha}^{-1}$ for MimGreen ${ }^{\circledR}$ and $30 €$ ha $^{-1}$ for Saikraft ${ }^{\circledR}$ due to the slower installation process. Barley straw mulching accounted for $200 € \mathrm{ha}^{-1}$ considering $20 \mathrm{~h}$ needed ha ${ }^{-1}$ mulch installation, $10 € \mathrm{~h}^{-1}$ of labour. Removal and retiring costs were considered $115 € \mathrm{ha}^{-1}$ for PE and half of that cost for Enviroplast ${ }^{\circledR}$ $\left(58 € \mathrm{ha}^{-1}\right)$. Weeding costs were $600 € \mathrm{ha}^{-1}$ for the handweeded plots (considering $20 \mathrm{hha}^{-1}, 10 € \mathrm{~h}^{-1}$ of labour, and three times weeding). The total costs for each treatment are summarized in Table 5.

Costs were considered the same for conventional and organic production (at Lleida) because differences were minimal. Irrigation costs were also considered the same for all mulching treatments despite around $15 \%$ of water was saved in the untreated control plots in several trials (Vázquez et al. 2011) because the cost of the water itself was only $6 \%$ of the total irrigation costs (Gutiérrez et al. 2005).

The considered commercial tomato fruit price to calculate incomes was $80 € \mathrm{t}^{-1}$ for conventional farming and $151.5 € \mathrm{t}^{-1}$ for organic farming at Lleida in 2010.

\section{Results and discussion}

Installation of the paper mulches in field had some constraints especially on windy days. MimGreen ${ }^{\circledR}$ suffered less fractures than Saikraft ${ }^{\circledR}$ but a correct soil preparation with few clods, a slight adaptation of the mulching machine and a slower installation reduces fracture risk. Installation of barley straw should be done mechanically but the bad results in weed control and yield did not motivate studying it further. During the cropping season we only observed problems in windy areas where paper could be torn off.

\subsection{Weed composition}

Weed composition changed within locations and years but the most frequent weed species found were the dicotyledonous species Convolvulus arvensis, Chenopodium album and Amaranthus spp. (Table 2). The competitive weed C. rotundus was the most frequent at Aragón in 2008 and was able to pierce plastic mulches. Total weed density varied between 11 and 171 plants $\mathrm{m}^{-2}$ in the untreated control plots at 63 DAT and was especially high at Aragón all 3 years $(95 \pm 11.6,102 \pm$ 14.0, and $84 \pm 14.6$ plants $\mathrm{m}^{-2}$ in 2006, 2007 and 2008 respectively), at Ciudad Real in $2007\left(171 \pm 36.0\right.$ plants $\left.\mathrm{m}^{-2}\right)$ and at Logroño in $2008\left(106 \pm 33.8\right.$ plants $\left.\mathrm{m}^{-2}\right)$.

\subsection{Weed control efficacy}

As some mulching materials became damaged in time, weed control efficacy only at the latest assessment date was provided (i.e., 63 DAT) showing control efficacy at the most disadvantageous moment. Weed control efficacy at 21 and 42 DAT was always similar or higher than at 63 DAT. In the 
Table 2 Weed density of the main weed species found in the different years and locations in the untreated control plots 63 days after transplanting (plants $\mathrm{m}^{-2}$ )

\begin{tabular}{|c|c|c|c|c|c|c|}
\hline & 2006 & & 2007 & & 2008 & \\
\hline \multirow[t]{4}{*}{ Aragón } & Amaranthus blitoides & $33 \pm 5.4$ & Amaranthus retroflexus & $48 \pm 8.6$ & Cyperus rotundus & $44 \pm 16.8$ \\
\hline & Setaria verticillata & $29 \pm 4.0$ & Xanthium spinosum & $18 \pm 2.9$ & Convolvulus arvensis & $15 \pm 2.4$ \\
\hline & Chenopodium album & $27 \pm 3.8$ & Echinochloa crus-galli & $14 \pm 2.8$ & Portulaca oleracea & $14 \pm 4.7$ \\
\hline & Total weeds & $95 \pm 11.6$ & Total weeds & $102 \pm 14.0$ & Total weeds & $84 \pm 14.6$ \\
\hline \multirow[t]{4}{*}{ Logroño } & Beta vulgaris & $9 \pm 0.8$ & Beta vulgaris & $7 \pm 2.6$ & Sinapis arvensis & $24 \pm 12.0$ \\
\hline & Convolvulus arvensis & $7 \pm 2.2$ & Convolvulus arvensis & $1 \pm 0.8$ & Veronica persica & $22 \pm 17.0$ \\
\hline & Borago officinalis & $6 \pm 3.0$ & Sonchus arvensis & $1 \pm 0.3$ & Polygonum aviculare & $13 \pm 5.3$ \\
\hline & Total weeds & $33 \pm 5.2$ & Total weeds & $11 \pm 1.9$ & Total weeds & $106 \pm 33.8$ \\
\hline \multirow[t]{4}{*}{ Lleida } & Amaranthus retroflexus & $44 \pm 17.7^{\mathrm{a}}$ & Amaranthus retroflexus & $32 \pm 10.0^{\mathrm{a}}$ & Amaranthus retroflexus & $83 \pm 3.6^{\mathrm{a}}$ \\
\hline & Chenopodium album & $9 \pm 3.8^{\mathrm{a}}$ & Chenopodium album & $7 \pm 3.6^{\mathrm{a}}$ & Chenopodium album & $9 \pm 2.3^{\mathrm{a}}$ \\
\hline & Convolvulus arvensis & $2 \pm 1.3^{\mathrm{a}}$ & Convolvulus arvensis & $8 \pm 4.0^{\mathrm{a}}$ & Convolvulus arvensis & $7 \pm 2.4^{\mathrm{a}}$ \\
\hline & Total weeds & $52 \pm 14.7^{\mathrm{a}}$ & Total weeds & $51 \pm 15.8^{\mathrm{a}}$ & Total weeds & $91 \pm 3.0^{\mathrm{a}}$ \\
\hline \multirow[t]{4}{*}{ Ciudad Real } & Anthemis arvensis & $12 \pm 3.4$ & Amaranthus albus & $106 \pm 36.3$ & Convolvulus arvensis & $12 \pm 7.3$ \\
\hline & Convolvulus arvensis & $6 \pm 3.6$ & Chenopodium album & $23 \pm 19.0$ & Matricaria chamomila & $9 \pm 8.1$ \\
\hline & Amaranthus albus & $6 \pm 2.7$ & Diplotaxis virgata & $18 \pm 5.3$ & Amaranthus albus & $5 \pm 3.4$ \\
\hline & Total weeds & $44 \pm 4.1$ & Total weeds & $171 \pm 36.0$ & Total weeds & $35 \pm 15.8$ \\
\hline
\end{tabular}

$\mathrm{Mean} \pm \mathrm{SE}$

${ }^{\mathrm{a}}$ Weed cover $(\%)$

tested semi-arid conditions, the biodegradable plastic mulches as well as the tested paper mulches were generally capable to reduce weed biomass as much as PE, as found by Radics et al. (2006) and Harrington and Bedford (2004) in other climatic conditions, except in the case of $C$. rotundus, which was only controlled with paper mulch as also found by Shogren and Hochmuth (2004) and Anzalone et al. (2010). An exception to these trends was the bad weed control achieved in 2008 by several materials at Aragón because persistent rainfall after mulching caused a delayed planting, so that several materials were already damaged when the crop was planted.
The main factor causing significant interactions year $\times$ treatment was the irregular weed control efficacy of barley straw mulch. In some locations, barley seeds were carried with the straw, germinated and caused an additional weed problem while in other cases straw mulch reduced weed emergence effectively (Table 3 ). The medium or irregular weed control effect of barley straw has been reported for other crops (Alcántara et al. 2007; Woldetsadik et al. 2003). The effective use of barley straw for weed control needs more research, e.g. checking the effect of different qualities of straw considering its length or finding the way to hinder the wind to blow it away.

Table 3 Weed control 63 days after transplanting depending on the treatment for the different locations and years

\begin{tabular}{|c|c|c|c|c|c|c|c|c|c|c|}
\hline \multirow[t]{2}{*}{ Efficacy (\%) } & \multicolumn{3}{|c|}{ Aragón } & \multirow{2}{*}{$\begin{array}{l}\text { Logroño } \\
\text { Mean }\end{array}$} & \multicolumn{3}{|c|}{ Lleida } & \multicolumn{3}{|c|}{ Ciudad Real } \\
\hline & 2006 & 2007 & 2008 & & 2006 & 2007 & 2008 & 2006 & 2007 & 2008 \\
\hline Manual weeding & $85 \mathrm{~b}$ & $89 \mathrm{c}$ & $39 \mathrm{bc}$ & $74 \mathrm{c}$ & $82 \mathrm{a}$ & $77 \mathrm{bc}$ & $80 \mathrm{c}$ & $100 \mathrm{ab}$ & 99 a & $89 \mathrm{bc}$ \\
\hline Polyethylene & $100 \mathrm{a}$ & $100 \mathrm{a}$ & $71 \mathrm{ab}$ & $100 \mathrm{a}$ & $97 \mathrm{a}$ & 99 a & $100 \mathrm{a}$ & $100 \mathrm{a}$ & $100 \mathrm{a}$ & $100 \mathrm{a}$ \\
\hline Mater- $\mathrm{Bi}{ }^{\circledR}$ & 99 a & $99 a b$ & $44 \mathrm{bc}$ & $91 \mathrm{~b}$ & $93 \mathrm{a}$ & $96 \mathrm{ab}$ & $100 \mathrm{ab}$ & $100 \mathrm{ab}$ & 99 a & $97 \mathrm{ab}$ \\
\hline Biofilm ${ }^{\circledR}$ & 98 a & $96 \mathrm{bc}$ & $5 \mathrm{c}$ & $87 \mathrm{bc}$ & $85 \mathrm{a}$ & $91 \mathrm{ab}$ & $99 \mathrm{~b}$ & $100 \mathrm{ab}$ & 99 a & $98 \mathrm{ab}$ \\
\hline Enviroplast ${ }^{\circledR}$ & 99 a & $99 a b$ & $69 \mathrm{ab}$ & - & - & - & - & $100 \mathrm{a}$ & 99 a & $100 \mathrm{a}$ \\
\hline MimGreen ${ }^{\circledR}$ & $100 \mathrm{a}$ & $93 \mathrm{bc}$ & $87 \mathrm{ab}$ & $90 \mathrm{bc}$ & $93 \mathrm{a}$ & $96 \mathrm{ab}$ & $100 \mathrm{a}$ & $100 \mathrm{ab}$ & $100 \mathrm{a}$ & $100 \mathrm{a}$ \\
\hline Saikraft ${ }^{\circledR}$ & $96 a b$ & $93 \mathrm{bc}$ & $94 \mathrm{a}$ & $78 \mathrm{bc}$ & $84 \mathrm{a}$ & $94 \mathrm{ab}$ & $99 \mathrm{ab}$ & $99 \mathrm{~b}$ & $100 \mathrm{a}$ & $84 \mathrm{c}$ \\
\hline Barley straw & $34 \mathrm{c}$ & $42 \mathrm{~d}$ & $71 \mathrm{ab}$ & $16 \mathrm{~d}$ & $91 \mathrm{a}$ & $61 \mathrm{c}$ & $54 \mathrm{~d}$ & $97 \mathrm{c}$ & $96 \mathrm{a}$ & $92 \mathrm{bc}$ \\
\hline
\end{tabular}

Data are back-transformed ls means from $a \sin (\sqrt{(x / 100)})$ after analysis. Means are only shown for the locations without significant interaction year $\times$ treatment. Different letters within each location and year refer to statistically significant differences according to Duncan's mean separation test at $P<0.05$ 


\subsection{Weed biomass}

The interaction year $\times$ treatment was significant for weed biomass in all locations except Ciudad Real. Despite the interaction, all mulching treatments drastically reduced weed biomass except barley straw and Biofilm ${ }^{\circledR}$, Mater-Bi ${ }^{\circledR}$ and $\mathrm{PE}$ in Aragón in 2008 due to the mentioned problems in timing and to the massive presence of $C$. rotundus capable to pierce the plastics. Plastic mulches reduced weed biomass $87-100 \%$ compared to the biomass found in the untreated plots (data not shown). The paper mulches generally reduced weed biomass efficiently but were irregular depending on the year (80$99 \%$ weed biomass reduction); barley straw achieved the lowest biomass reduction from $40 \%$ to $97 \%$. Thus, the biodegradable plastic mulches as well as the tested paper mulches were generally capable of reducing weed biomass as much as PE.

\subsection{Yield}

Weed control is absolutely necessary for this crop in the tested conditions because a yield decrease of 24 to $68 \%$ was found in the untreated control (Table 4). Yield achieved in the plastic and paper mulched plots was similar to plots mulched with PE (Table 4) as found also by for paper mulch in tomato, lettuce and summer squash by Anderson et al. (1995), Toth et al. (2008) and Coolong (2010), respectively, as well as by Martín-Closas et al. (2003) for biodegradable plastic mulches in tomato.

Barley straw achieved irregular yield, usually lower than with other mulching treatments as reported for different crops (Woldetsadik et al. 2003; Alcántara et al. 2007; Anzalone et al. 2010).

Higher yield in the mulched plots compared to the untreated control plots was probably not caused by the combination of weed control and other advantages of mulching (temperature, moisture retention, etc.) because yield in the manually weeded plots was within the highest in all cases excepting Lleida (Table 4). Thus, elimination of weed competition either by mulch or manually was probably the main cause for high yield. This was probably due to the rapid soil coverage achieved by this crop as found also for cabbage (Tiwari et al. 2003) opposite to other crops as okra, where mulching itself increases yield significantly (Tiwari et al. 1998).

Yield obtained each year differed considerably between locations: highest yield was obtained in 2006 and 2007 in Lleida and 2006 in Logroño, while 2008 was the year with highest yield in Aragón and 2006 and 2008 in Ciudad Real (Fig. 2).

These differences were probably caused by edaphic and climatic differences between locations and years. Regressions of yield related to efficacy were significant for all locations and years excepting Logroño 2007 which means that decreasing in yield correlates with control efficacy decrease and is caused only by weeds (Fig. 2). The homogeneity of regression coefficient tests showed that lines were parallel all 3 years in each location so that the test was performed in all cases. The results indicate that a common regression coefficient value for the equation $f(x)=y_{0}+a x$ of $a=0.387 \pm 0.056$ could be estimated. This value indicates that weed competition was responsible for a yield decrease of 3.3 to 4.4 tha $^{-1}$ for each $10 \%$ of efficacy loss. The $r^{2}$ values of the regressions comprised between $13 \%$ and $77 \%$ means that $13 \%$ and $77 \%$ of the yield variance was explained by efficacy (data not shown) demonstrating that weeds are still an important issue for crop production (Oerke 2006).

The mean percent of maximum yield reduction comparing maximum and minimum yields each year in the trials varied between $26.8 \%$ and $71.8 \%$. A direct measure of weed

Table 4 Tomato yield $\left(\mathrm{t} \mathrm{ha}^{-1}\right)$

\begin{tabular}{|c|c|c|c|c|c|c|}
\hline \multirow[t]{2}{*}{ Treatment/tomato yield $\left(\mathrm{t} \mathrm{ha}^{-1}\right)$} & \multirow{2}{*}{$\begin{array}{l}\text { Aragón } \\
\text { Mean }\end{array}$} & \multicolumn{3}{|l|}{$\operatorname{Logroño~}^{a}$} & \multirow{2}{*}{$\begin{array}{l}\text { Lleida }^{\mathrm{a}} \\
\text { Mean }\end{array}$} & \multirow{2}{*}{$\begin{array}{l}\text { Ciudad Real } \\
\text { Mean }\end{array}$} \\
\hline & & 2006 & 2007 & 2008 & & \\
\hline Untreated control & $64(71) \mathrm{c}$ & $104(70) \mathrm{e}$ & $97(78) \mathrm{c}$ & $30(28) \mathrm{d}$ & $30(42) \mathrm{d}$ & $88(75) \mathrm{c}$ \\
\hline Manual weeding & $96(107) \mathrm{a}$ & $172(115) \mathrm{a}$ & $133(106) \mathrm{a}$ & $96(89) \mathrm{ab}$ & $56(79) \mathrm{bc}$ & $116(98) a b$ \\
\hline Polyethylene & $90(100) a b$ & $149(100) \mathrm{cd}$ & $125(100) \mathrm{ab}$ & $108(100)$ a & $71(100) \mathrm{a}$ & $118(100) a b$ \\
\hline Mater-Bi® & $89(99) a b$ & $153(103) \mathrm{bc}$ & $113(90)$ bc & $100(93) \mathrm{a}$ & $71(100) \mathrm{a}$ & $124(105) \mathrm{a}$ \\
\hline Biofilm ${ }^{\circledR}$ & $83(92) \mathrm{ab}$ & $138(93) \mathrm{d}$ & $112(90) b c$ & $99(92)$ a & $68(96) \mathrm{a}$ & $119(101) a b$ \\
\hline Enviroplast ${ }^{\circledR}$ & $82(91) a b$ & - & - & - & - & 123 (104) a \\
\hline MimGreen ${ }^{\circledR}$ & $97(108)$ a & $153(103) \mathrm{bc}$ & $125(100) \mathrm{ab}$ & $83(77) b c$ & $65(92) a b$ & $115(97) a b$ \\
\hline Saikraft ${ }^{\circledR}$ & $95(106) \mathrm{a}$ & $161(108) b$ & $113(90) \mathrm{bc}$ & $78(72) \mathrm{c}$ & $58(82) \mathrm{bc}$ & $106(90) \mathrm{b}$ \\
\hline Barley straw & $75(83) b c$ & $150(101) \mathrm{cd}$ & $123(98) \mathrm{ab}$ & $67(62) \mathrm{c}$ & $54(76) \mathrm{c}$ & $109(92) a b$ \\
\hline
\end{tabular}

Means are only shown for the locations without significant interaction year $\times$ treatment. In parentheses, relative value compared to polyethylene. Different letters within each location refer to statistically significant differences according to Duncan's mean separation test at $P<0.05$

${ }^{a}$ Back-transformed from $(x)^{2}$ 
Fig. 2 Yearly linear regression between weed control efficacy (\%) 63 days after transplanting and tomato yield in Aragón, Logroño, Lleida and Ciudad Real following the equation $f(x)=y_{0}+a x$. Mean values of all mulching materials are shown
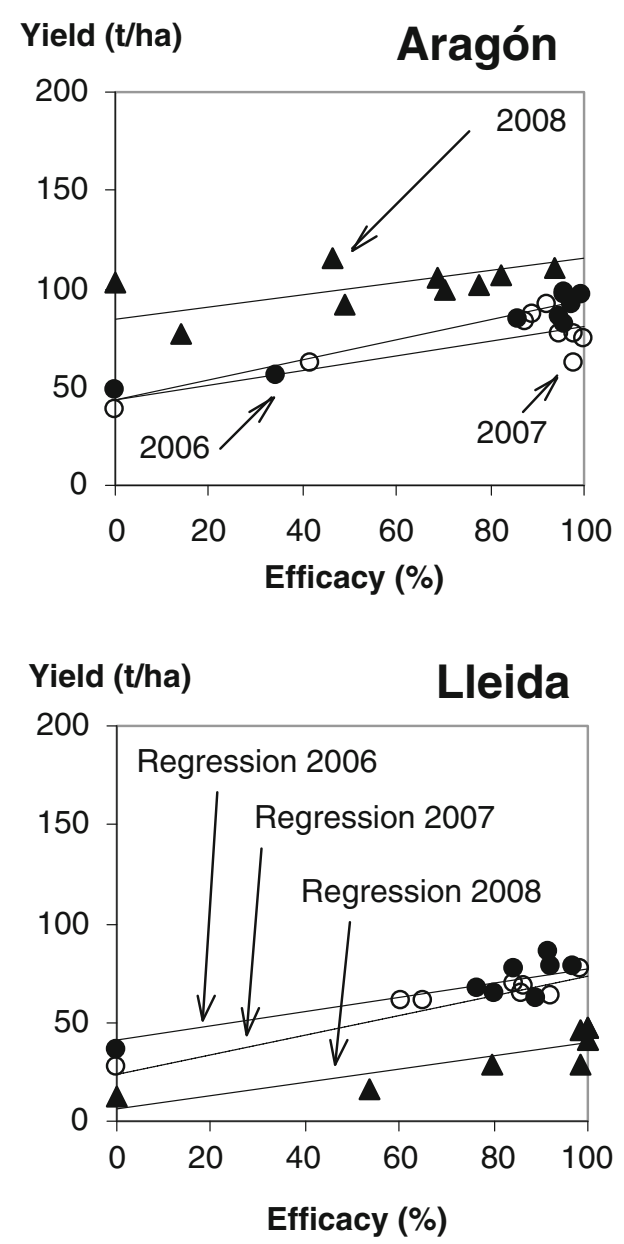
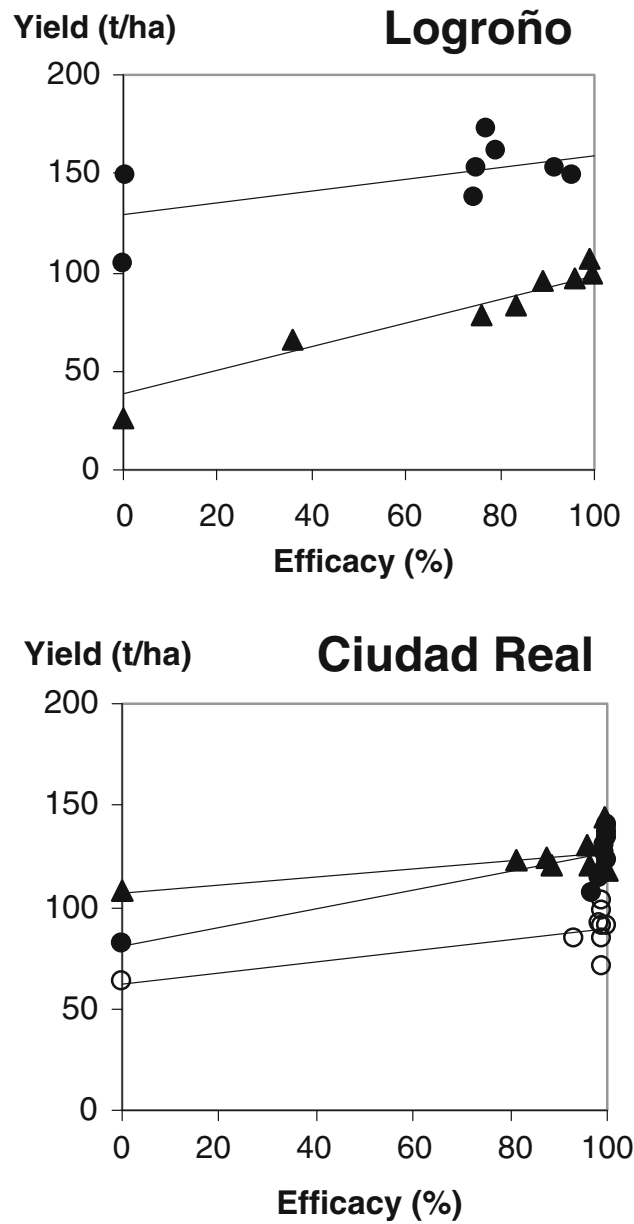

competition was calculated by comparing yield of untreated and manually weeded plots resulting in yield losses of $34 \%$, $39 \%, 27 \%, 68 \%, 46 \%$ and $24 \%$ for Aragón, Logroño 2006, Logroño 2007, Logroño 2008, Lleida and Ciudad Real, respectively (based on data of Table 4).
3.5 Economic study

The cost of the mulching materials had the highest influence on final costs and Mater-Bi ${ }^{\circledR}$, Biofilm ${ }^{\circledR}$ and MimGreen ${ }^{\circledR}$ had the highest global cost (Table 5). However, high yield was

Table 5 Costs, income and benefit $\left(€ \mathrm{ha}^{-1}\right)$

\begin{tabular}{|c|c|c|c|c|c|c|c|c|c|c|c|}
\hline \multirow[t]{2}{*}{ Treatment } & \multirow{2}{*}{$\begin{array}{l}\text { Costs } \\
\text { Total cost } \\
\text { (\% of polyethylene } \\
\text { mulching) }\end{array}$} & \multicolumn{4}{|l|}{ Income } & \multicolumn{6}{|l|}{ Benefit } \\
\hline & & Aragón & Logroño & Lleida & $\begin{array}{l}\text { Ciudad } \\
\text { Real }\end{array}$ & Aragón & Logroño & Lleida & $\begin{array}{l}\text { Ciudad } \\
\text { Real }\end{array}$ & Mean & $\begin{array}{l}\% \text { compared to } \\
\text { polyethylene }\end{array}$ \\
\hline Untreated control & $6,278(95)$ & 5,088 & 6,192 & 4,514 & 7,040 & $-1,190$ & -83 & $-2,836$ & 762 & -837 & -30 \\
\hline Manual weeding & $6,878(104)$ & 7,688 & 10,688 & 8,423 & 9,280 & 861 & 3,861 & 1,545 & 2,453 & 2,180 & 79 \\
\hline Polyethylene & $6,639(100)$ & 7,224 & 10,200 & 10,787 & 9,440 & 585 & 3,561 & 4,148 & 2,761 & 2,764 & 100 \\
\hline Mater-Bi® & $7,309(110)$ & 7,144 & 9,752 & 10,787 & 9,920 & -165 & 2,443 & 3,478 & 2,611 & 2,092 & 76 \\
\hline 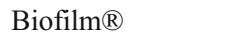 & $7,161(108)$ & 6,672 & 9,304 & 10,257 & 9,520 & -489 & 2,143 & 3,096 & 2,359 & 1,777 & 64 \\
\hline Enviroplast $\mathbb{R}$ & $6,697(101)$ & 6,432 & - & - & 9,840 & -247 & - & - & 3,143 & 1,448 & 52 \\
\hline MimGreen ${ }^{\circledR}$ & 7,209 (109) & 7,656 & 9,624 & 9,787 & 9,200 & 447 & 2,199 & 2,578 & 1,991 & 1,804 & 65 \\
\hline Saikraft巴 & $6,802(102)$ & 7,576 & 9,408 & 8,817 & 8,480 & 771 & 2,603 & 2,015 & 1,675 & 1,766 & 64 \\
\hline Barley straw & $6,678(101)$ & 5,976 & 9,056 & 8,242 & 8,720 & -702 & 2,378 & 1,564 & 2,042 & 1,321 & 48 \\
\hline
\end{tabular}

Marketable price of $80 € \mathrm{t}^{-1}$ for conventional farming and of $151.5 € \mathrm{t}^{-1}$ for organic farming at Lleida 
generally also achieved in these treatments. At Lleida, the sensibly higher price of the organic marketable tomato increased the benefit of most mulching treatments considerably, compensating lower yields and provoking higher benefit of most mulching materials compared to other locations (Table 5).

As it happened with weed control and yield, also from the economic point of view, PE mulching was difficult to improve despite environmental costs of $\mathrm{PE}$ removal and retiring were included in this study. However, paper mulches and biodegradable mulching materials gave within highest benefits in both the high-yield locations of Logroño and Ciudad Real and in the loweryield locations of Aragón and Lleida. High benefit found in manually weeded plots shows that this weed control method might be appropriate for fields with low weed density. However, labour in Western Europe is scarce and increasingly expensive.

The percentage of weed management cost on total costs considered as mulching material, removal and retiring costs, mulching installation and other weeding costs ranged between $6 \%$ (for PE) and 16\% (for Mater-Bi ${ }^{\circledR}$; Table 5), which was lower than found by Clark et al. (1998), who estimated weeding costs of $22-25 \%$ for different tomato management systems.

\section{Conclusion}

Weed control was necessary in the transplanted tomato crop to obtain benefits. Good weed control and high yield found for biodegradable plastics demonstrate that they are technically viable alternatives to PE. Also the results of paper mulches, which were slightly worse, were still similar to $\mathrm{PE}$ and were the only materials able to control purple nutsedge emergence, although they are more difficult to place in the field and can suffer fractures. From the economic point of view, the biodegradable materials gave benefits, though lower than PE. However, market price of the mulching materials is the most determining economic factor, so that PE will probably still be the most common mulching material despite its waste problem unless it was forbidden or the other materials were sold at lower cost. Manual weeding is also found to be an interesting alternative from the economic point of view, provided that weed density was low and labour costs do not increase.

Acknowledgements This work has been funded by the Project RTA2005-00189-C05 of the INIA in Spain. The authors specially thank the valuable technical assistance of F. Arrieta, J.M. Royo, J. A. Alins, M. León, C. Asensio, P. Vivo, J. García, I. Tenas, J. Villena and I. Mancebo for their help during harvest and counting weeds. We also thank the companies Saica, Gemplast, Barbier, MimCord S.A.and Novamont S.p.A. for their collaboration providing their materials.

\section{References}

Alcántara C, Jiménez A, Balsera A (2007) Manejo ecológico de hierbas. Influencia sobre la producción de tomate y pimiento. Phytoma España 194:44-48

Anderson D, Garisto M, Bourrut J, Schonbeck M, Jaye R, Wurzberger A, De Gregorio R (1995) Evaluation of a paper mulch made from recycled materials as an alternative to plastic film mulch for vegetables. J Sustain Agric 7:39-61

Anderson RL (2007) Managing weeds with a dualistic approach of prevention and control. A review. Agron Sustain Dev 27:13-18

Anzalone A, Cirujeda A, Pardo G, Zaragoza C (2010) Effect of biodegradable mulch materials on weed control in processing tomato. Weed Technol 24:369-377. doi:10.1614/WT-09-020.1

Bowley SR (1999) A Hitchhiker's Guide to Statistics in Plant Biology. Any Old Subject Books, Guelph, Ontario, Canada, $250 \mathrm{p}$

Clark MS, Ferris H, Klansky K, Lanini WT, van Bruggen AHC, Zalom FG (1998) Agronomic, economic, and environmental comparison of pest management in conventional and alternative tomato and corn systems in northern California. Agr Ecosyst Environ 68:51-71

Coolong T (2010) Performance of paper mulches using a mechanical plastic layer and water wheel transplanter for the production of summer squash. Horttech 20:319-324

Dagnelie P (1975) Théorie et Méthodes Statistiques. Aplications agronomiques. Les Presses Agronomiques de Gembloux A.S.B.L., vol. 2, $463 \mathrm{pp}$

Gutiérrez M, Bruna P, Vallés M (2005) El cultivo de tomate de industria en Aragón. Informaciones Técnicas del Departamento de Agricultura y Alimentación del Gobierno de Aragón 163, 1-4. https://webmail. aragon.es/webmail/attach/PUBLICACIONES_163_INFORMA CIONES TECNICAS_2005.pdf

Harrington $\mathrm{K} \overline{\mathrm{C}}$, Bedford $\overline{\mathrm{TA}}$ (2004) Control of weeds by paper mulch in vegetables and trees. New Zealand Plant Protection Series. Proceedings of the 57th Annual Meeting of the New Zealand Plant Protection Society, Hamilton, New Zealand

Maillet J, Abdel Fatah H (1983) Etudes preliminaires sur la concurrence entre Solanum nigrum ssp. eunigrum L. et Lycopersicon esculentum Mill en culture repiquee. Weed Res 23:217-219

MARM Ministerio de Medio Ambiente y Medio Rural y Marino (2011a) http://www.mapa.es/estadistica/pags/anuario/2009/ AE_2009_13_01_03_01.pdf. Accessed January 21st 2011

MARM Ministerio de Medio Ambiente (2011b) Borrador del I Plan Nacional de Residuos de Plásticos de Uso Agrario http://www. $\mathrm{mma}$.es/secciones/calidad_contaminacion/residuos/planifica cion residuos/pdf/borradorpnir anexo11.pdf. Accessed January 21st 2011

Martín-Closas L, Soler J, Pelacho AM (2003) Effect of different biodegradable mulch materials on an organic tomato production system. KTBL Darmstadt Schrift 414:78-85

Oerke EC (2006) Crop losses to pests. Centenary review. J Agr Sci 144:31-43

Patrap M, Kumar BV, Shaik M (1997) Effect of herbicides and time of weeding on weed control and fruit yield of tomato. Crop Res 14:113-117

Salemi F, Lamagna G, Coco V, Barone LG (2008) Proceedings of the International Symposium on High Technology for Greenhouse System Management. Acta Hort 801:203-210

SAS Institute (1991) Sas Systems for Linear Models. SAS Series in Statistical Applications. SAS Institute, Cary NC, USA

Radics L, Szekelyne EB, Pusztai P, Horvath K (2006) Role of mulching in weed control of organic tomato. 23rd German Conference on Weed Biology and Weed Control, 643-650

Scott G (2005) Biodegradable plastics in agriculture. In: Smith Woodhead R (ed) Biodegradable Polymers for Industrial Applications. R. Smith Woodhead, London, UK, pp 1-20 
Shogren RI, Hochmuth RC (2004) Field evaluation of watermelon grown on paper-polymerized vegetable oil mulches. HortSci 39:1588-1591

Tabaglio V, Gavazzi C, Schulz M, Marocco A (2008) Alternative weed control using the allelopathic effect of natural benzoxazinoids from rye Munch. Agron Sustain Dev 28:397-401

Tei F (2001) Il disherbo delle colture orticole. In: Catizone P, Zanin G (eds) Malerbologia. Patron Edit, Bologna, Italy, pp 777-814

Tiwari KN, Mal PK, Singh RM, Chattopadhyay A (1998) Response of okra (Abelmoschus esculentus (L.) Moench.) to drip irrigation under mulch and non-mulch conditions. Agr Water Manage 38:91-102

Tiwari KN, Singh A, Mal PK (2003) Effect of drip irrigation on yield of cabbage (Brassica oleracea L. var. capitata). Agr Water Manage 58:19-28
Toth N, Fabek S, Custic MH, Zutic I, Borosic J (2008) Organic soil mulching impacts on lettuce agronomic traits. Cereal Res Commun 36:395-398

Vandenberg J, Tiessen H (1972) Influence of wax-coated and polyethylene-coated paper mulch on growth and flowering of tomato. HortSci 7:464-465

Vázquez N, Huete J, Pardo A, Suso ML, Tobar V (2011) Use of soil moisture sensors for automatic high-frequency drip irrigation in processing tomato. Acta Hort. (ISHS) 922, 229-235

Weaver SE, Tan CS (1983) Critical period of weed interference in transplanted tomato: growth analysis. Weed Sci 31:476-481

William RD, Warren GF (1975) Competition between purple nutsedge and vegetables. Weed Sci 23:317-323

Woldetsadik K, Gertsson U, Ascard J (2003) Response of shallots to mulching and nitrogen fertilization. HortSci 38:217-221 